\title{
Review of The Arid Lands. History, Power, Knowledge by Diana K. Davis
}

Tor A. Benjaminsen(1)

\author{
Book details \\ Diana K. Davis \\ Cambridge, MA: MIT Press; 2016. \\ 271 pp; ISBN: 978-0-262-034552-4 \\ Keywords: Drylands, Desertification, Pastoralism
}

Drylands cover 40 to $45 \%$ of the earth's land surface and harbour about $38 \%$ of people on the planet. The UN has claimed that up to $70 \%$ of drylands suffer from desertification, affecting 168 countries globally. This has led to desertification becoming the first globally defined environmental issue.

Much has been written about problems with the idea of desertification and how it became such a powerful global narrative, despite lack of scientific support. While the colonial roots of this narrative have been acknowledged, often this literature has focused primarily on the last few decades.

The great achievement in this book by Diana Davis is that not only is the history of the desertification narrative summarised and contrasted to the current research frontier but this history is also told with more detail and within a longer time perspective than we have seen before. Such a historical approach helps us to further clarify and follow more carefully the interests of the powerful colonial actors behind the establishment of the narrative.

The author is trained as both a geographer and veterinarian and holds a position as a Professor of History at the University of California at Davis. She has, in particular, studied and written about the drylands of the Afghanistan to Pakistan border areas as well as those of Morocco and Algeria. She uses a historical political ecology approach, where power relations that form environmental governance are investigated from a historical perspective. In addition,

Correspondence: t.a.benjaminsen@nmbu.no

Department of International Environment and Development Studies (Noragric), Norwegian University of Life Sciences, PO Box 5003, 1432 Ås, Norway

Springer Open this is a political ecology that takes ecology seriously, reflecting the insights from non-equilibrium ecology that have been so important for the recent development of range science and for our general understanding of the dynamics of arid environments.

The book is relatively concise not only with 175 pages divided into six chapters but also with an extensive addition of 85 pages of notes including references. While other scholars who have written about the history of desertification have also traced this idea to the colonial period, Davis goes all the way back to the ancient Greek and Roman writers who reflected an image of deserts not as degraded environments but as exotic places with strange people who were variously depicted as rich in livestock, as fierce warriors, or simply as bandits.

It was only with European colonisation and the expansion of capitalism that the view emerged that dryland peoples are themselves responsible for creating deserts. There was a growing need to portray native land uses as destructive in order to justify dispossession of these peoples and to prepare for other land uses such as settler agriculture, state-led irrigation schemes or large-scale forest exploitation. Earlier in the colonial period, however, in the sixteenth and seventeenth centuries when colonisation had been less intense, the causes of environmental degradation had still often been seen to be linked to colonial activities such as plantation and logging. But with the intensification of colonialism during the nineteenth century, there was a shift in thinking towards blaming native land management practices for what the colonial gaze depicted as degraded landscapes. Increasingly, colonial officials, military officers, missionaries, and scientists accused the indigenous colonial 
subjects of creating their own misery by undermining their natural resource base. It became the civilising mission of Europeans to bring science and expertise to stop desertification, recreate the imagined forested landscapes of the past, and improve the lives of the colonial subjects.

The principal narrative that developed among colonial authorities was an assertion that dryland peoples have deforested their own landscapes, which again led to reduced rainfall and the creation of deserts. This is known as 'desiccation theory' and dominated European thinking about drylands in the colonies from early in the nineteenth century. Davis argues that the development of desiccation theory was intimately linked to the intensification of colonisation and the expansion of capitalism in the same period. Hence, desiccation theory served to justify dispossession and colonial capital accumulation - a process Davis calls 'accumulation by desertification'.

Although the term 'desertification' seems to have first been used by the French forester Lavauden in 1927 (Lavauden 1927), the idea had by then existed for at least 100 years. When the French invaded North Africa in 1830, desiccation theory was already established as a leading colonial narrative. Reflecting this view, a popular French magazine wrote in 1843: 'The Arabs never plant, but constantly destroy by grazing livestock and burning pastures'. Later, the British engineer William Willocks working in Egypt in the early twentieth century wrote in a similar vein: 'It is extraordinary how capable an Arab is in turning a country into a desert.' Davis also alludes to this narrative playing a role in supporting the Zionist cause in Palestine, mentioning for instance that the American influential conservationist C. Lowdermilk, in his popular book Palestine: Land of Promise, from 1944 blamed Arab Bedouin pastoralists for widespread desertification (Lowdermilk 1944).

But not only colonial authorities subscribed to the desertification narrative. After independence, it also fitted the interests of new national elites who emerged in particular in Africa. 'Such crisis narratives that blamed local peoples for desertification were immensely useful to colonial powers and newly independent rulers for justifying many political, social, and economic changes in the name of environmental protection', Davis writes (p. 142).

Furthermore, the book demonstrates how there are continuities from colonial policies to UN institutions today. For instance, the UN absorbed European understandings of arid lands and desertification, and UN agencies largely replaced colonial institutions as the main actors in supporting and reproducing the desertification narrative. In fact, after the United Nations Environment Programme (UNEP) was established in the 1970s, the first international conference that UNEP organised was on desertification as a global problem in 1977. The solution to the problem, as it had been during the colonial period, was seen to be expert-led, top-down initiatives totally neglecting the knowledge held by dryland peoples themselves. This approach also explains why there have been so many development failures in the drylands, says Davis.

The desertification narrative is today maintained primarily by the UN Convention to Combat Desertification (UNCCD). Davis notes that 'UNCCD restricts itself to a few "scientific experts", some of whom may be politically motivated, resulting in a mismatch between dryland ecological science and policy' and that 'effective policy in the drylands may need to come from somewhere other than UNCCD, because the organization has proven largely ineffective' (p. 162).

This is a strong but necessary critique. Arid land management is one of the several themes where there is a mismatch between science and policy. Another such theme is pastoralism. As $88 \%$ of the drylands are also rangelands, pastoralism remains an important sub-topic in this book. In fact, anyone interested in pastoral development, also outside the drylands, will find this a great and inspirational read. I found for instance numerous parallels with the history of Norwegian colonisation of Sámi reindeer herding areas in the Arctic.

Finally, we should not forget, however, that there have always been some critical voices around, and Davis mentions a couple of these from the colonial period: first, the French General Cavaignac's report from 1849 that included a critique, although gentle, of desiccation views and reflected a nuanced understanding of native land use in Algeria (Jacquot, 1849). And second, the French geographer de Gironcourt who argued against colonial views of desertification in today's Mali after a mission to the area in 1912-13, saying that the only visible environmental degradation taking place was caused by the French cutting down trees to feed their steam-engined boats on the Niger river and the Dakar-Bamako railway (Benjaminsen and Berge 2004). These dissenting voices were, however ignored, as Davis' book is likely to be ignored today by the UNCCD and other powerful actors who continue to formulate policies to 'save' the drylands from the people living there. But the more such well-documented critical political ecology is produced, the more difficult it will be to ignore.

\section{Competing interests}

The author declares that he has no competing interests.

Received: 21 July 2017 Accepted: 21 July 2017

Published online: 02 October 2017

\footnotetext{
References

Benjaminsen, T.A., and G. Berge. 2004. Myths of Timbuktu. From African El Dorado to desertification. International Journal of Political Economy 34 (1): 31-59. Jacquot, F. 1849. Expédition du Général Cavaignac dans le Sahara algérien. Paris: Gide et J. Baudry.

Lavauden, L. 1927. Les Forêts du Sahara. Paris: Berger-Levrault.

Lowdermilk, W.C. 1944. Palestine: Land of promise. New York: Harper and Brothers.
} 